\title{
MANAGEMENT OF BURNING MOUTH SYNDROME: A LITERATURE REVIEW
}

\author{
I Nyoman Gede Juwita Putra*, Riani Setiadhi ${ }^{* *}$
}

Keywords:

Burning Mouth

Syndrome,

Management,

Postmenopausal

women

\section{ABSTRACT}

Background: Burning mouth syndrome (BMS) is a chronic idiopathic oral dysaesthesia that presents as a burning sensation in the oral cavity usually without any specific oral lesions or laboratory findings. Burning sensations may appear on the buccal mucosa, hard and soft palate, tongue and lips. BMS appears to be more prevalent in postmenopausal women. The term menopause is often used for a condition in which the permanent cessation of the primary function of the ovaries in humans that occurs especially in middle-aged women. Available evidence suggested that BMS is a multifactorial disorder with physiological basis. Pathophysiology of BMS remains unclear. The etiopathogenesis in most patients who complain of burning sensations have interactions with several factors such as local, systemic, and/ or psychogenic factors. The aim of this literature review was to assess and evaluate the management of BMS comprehensively.

Discussion: The therapy of BMS including hormone replacement therapy, systemically therapy, such as antidepressants, clonazepam and topical medication (clonidine and capsaicin) and reassurance as the stress management.

Conclusion: Proper management of the BMS involves the combination of pharmacologic treatment and psychotherapy, as well as reassurance is an important thing

\section{INTRODUCTION}

Burning mouth syndrome (BMS) is an idiopathic burning discomfort or pain affecting people with clinically normal mucosa, defined as a spontaneous syndrome of burning sensation, discomfort, pain, irritation or rawness of the tongue, lips or oral cavity, often without organic cause that present a difficult diagnosis for many clinicians. ${ }^{1,2,3}$

Prevalence rate between $0,7-2,6 \%$ reported from National Institutes of Health (NIH) survey estimating close to 1 million burning mouth sufferers in America. ${ }^{4}$ It occurs more commonly in middle-aged and elderly women, particularly following menopause at 55 to 60 years and being rare under 30 years with an overall prevalence ranging from $0,7 \%$ to $7 \%$ and a prevalence up to $12 \%$ to $18 \%$ for post-menopausal women with BMS. ${ }^{5,6}$ In recent years, the prevalence of BMS increased and it has become a common chronic orofacial pain disorder that reported prevalence in general population varies from $0,7 \%$ to $15 \%{ }^{4}$. BMS exhibit significant female predilection and the ratio between females and males varies from $3: 1$ to $16: 1$ in various literature studies. ${ }^{7}$

Therefore, the aim of this literature review is to discuss the management of burning mouth syndrome comprehensively in postmenopausal women and may be practiced by a general practitioner dentist when encountering a patient with the BMS complain.

\section{LITERATURE REVIEW}

Burning Mouth Syndrome (BMS) is an idiopathic burning state accompanied by uncom- 
fortable pain that is generally on the tongue, mucous membranes and lips without the presence of medical, dental and laboratory findings lasting at least 4-6 months. The International Association of Pain studies stated that the pain felt lasted 4-6 months without clinical and laboratory findings. ${ }^{2,7-9}$

Most of studies suggested that majority of patient with BMS are middle-aged women in postmenopausal phase. ${ }^{7}$ The mean age of BMS patients is between 55 to 60 years. The term menopause is often used for a condition in which the permanent cessation of the primary function of the ovaries in humans that occurs especially in middle-aged women. The increasing population of menopausal women associated with other systemic disorders such as osteoporosis, cardiovascular disorders, cervical cancer, breast cancer and other systemic disorders, makes us think of other problems that can arise in this group. Signs and symptoms of menopause depend on a woman's lifestyle, rural-urban division, and economic status. $^{10}$

Available evidence suggested that BMS is a multifactorial disorder with physiological basis. Pathophysiology of BMS remains unclear. The etiopathogenesis of BMS is very complex and in most patients who complain of burning sensations have interactions with several factors such as local, systemic, and/ or psychogenic factors. $6,8,9$

Local factors which could conceivably cause BMS in the oral cavity include dental treatment, candidiasis, bacterial infection, allergies, TMJ-dysfunctions and dysfunctions of salivary glands. Different designs of denture problems become an important local etiological factors. Candidiasis have been reported to be a common etiological factor in BMS, but it was a minor importance. Candida species and coliforms (Enterobacter and Klebsiella) have been found to be higher in patients with BMS. Local allergic reaction has been pointed out as an etiological factor for BMS. Some patient with BMS was caused by allergy of mercury and some patient whom wearing denture was allergy to substance in denture. Oral dysfunction as important local factor and parafunction, also dysfunction in the muscle of the stomatognathic system are the most frequent causes of BMS and 51/150 (34\%) BMS patients usually had inadequate saliva and suffered from oral dryness. The other contributing factors such as radiation therapy, systemic disorders and side effects of different drugs are important factors that cause a decrease in salivary flow rate..$^{9,10,14}$

Systemic factors as one of etiologic factor of BMS can be divided into deficiencies of different types and immunological disturbances and also the side-effect of drugs/therapy. Iron deficiency is a common etiologic factor in BMS; whereas there is significant proportion of the patient had either B1-, B2- or B6- deficiency or combined deficiency of these vitamins. The lack of folic acid could be a causative factor and that in some case menopausal factor might be involved. Women with climacteric problems had oral symptoms and the most common symptoms are BMS. The high protein, potassium and phosphate concentrations in saliva in patients with idiopathic glossodynia might indicate that hormonal imbalance could cause this type of sore tongue. Nearly $50 \%$ patients with BMS were found to have some clinical evidence of an immunologically mediated disease. ${ }^{7,10,13,14}$

Psychological and psychosocial factors seem to play an important role in facial and orofacial pain disorders and atypical facial pain disorders appeared to be linked together with stressful life events and long-term problems. 
Table 1. Subtypes of burning mouth syndrome (BMS). ${ }^{1,2,7,8}$

\begin{tabular}{|c|c|c|c|}
\hline Subtypes & Prevalence (\%) & Characteristic & $\begin{array}{l}\text { Associated } \\
\text { etiologies }\end{array}$ \\
\hline Type 1 & 35 & $\begin{array}{l}\text { Characterized by progressive pain, } \\
\text { burning sensation of the mouth does } \\
\text { not appear when waking up, but the } \\
\text { pain will increase in the late morning, } \\
\text { uncomfortable intensity continues to } \\
\text { increase at night. This sensation will } \\
\text { appear every day. }\end{array}$ & $\begin{array}{l}\text { Systemic disease and } \\
\text { nutritional deficiencies }\end{array}$ \\
\hline Type 2 & 55 & $\begin{array}{l}\text { Burning sensation appears constantly } \\
\text { throughout the day, and occurs every } \\
\text { day, resulting in patients having } \\
\text { difficulty sleeping }\end{array}$ & $\begin{array}{l}\text { Psychological disorders } \\
\text { and mood change }\end{array}$ \\
\hline Type 3 & 10 & $\begin{array}{l}\text { Symptoms of burning sensation } \\
\text { appear intermittent, appearance has a } \\
\text { day interval, usually appears in } \\
\text { unusual areas such as the floor of the } \\
\text { mouth and buccal mucosa }\end{array}$ & $\begin{array}{l}\text { Anxiety and allergic } \\
\text { reaction }\end{array}$ \\
\hline
\end{tabular}

Psychogenic factor have been considered as the most and major etiological factors in BMS after iron deficiency. Psychological stress in connection with loss due to death or separation are associated with BMS and, with the exception of local treatment, it is considered that treatment should be focused on the underlying depression. Anxiety is more characteristic symptom for BMS than depression and together with cancerphobia could be causative factor. Cancerphobia as a possible etiologic factor for idiopathic BMS. ${ }^{1,13,15}$

Based on a related etiology, BMS can be divided into primary and secondary types, which the primary type includes idiopathic, non-neuropathic, while the secondary type (which is now more commonly called burning mouth sensation) is more related to organic or therapeutic factors. Burning mouth syndrome has been divided into three subtypes based on the daily variation of the symptoms in table $1 .^{7,8}$

In establishing a BMS diagnosis, it requires careful analysis of the symptoms of each individual. The main symptoms of burning pain in the oral cavity does not subside for at least 4-6 months, and continue to occur throughout the day. In addition, the burning sensation does not interfere with sleep and does not worsen but can be reduced by eating or drinking. Other oral symptoms such as dysgeusia and xerostomia and the presence of sensory / chemo-sensory anomalies, mood change, and specific disorders of the patient's personality traits can also help identify BMS. Clinical diagnosis can be obtained based on a patient's history of systemic and dental diseases and careful analysis of the diagnosis based on physical and laboratory examinations. ${ }^{6}$

\section{DISCUSSION}

Since BMS is a disorder caused by multifactorial factors, the therapy must be comprehensive including hormone replacement therapy, systemically therapy, and topical medication as well as reassurance as the stress management. ${ }^{6}$

\section{Hormone Replacement Therapy (HRT)}

Burning mouth sensation is often experienced in climacteric women. Previous study examined the relationship between oral cavity discomfort in postmenopausal women by 149 people and found that the prevalence of women with oral discomfort was higher (43\%) 
Table 2. Drugs (systemically \& topical) as the treatment of Burning Mouth Syndrome (BMS).

\begin{tabular}{|c|c|c|c|c|}
\hline No. & Author & Therapy & Doses & Results \\
\hline 1. & $\begin{array}{l}\text { De Castro, et al } \\
(2014)^{16} \text { and } \\
\text { Gremeau-Richard } \\
(2010))^{17}\end{array}$ & $\begin{array}{l}\text { Topical } \\
\text { Clonazepam }\end{array}$ & $\begin{array}{l}\text { Suck } 1 \text { tablet } 1 \mathrm{mg} \\
\text { near the pain site }\end{array}$ & $\begin{array}{l}\text { Greater reduction of pain score in } \\
\text { clonazepam treated patients than in } \\
\text { placebo-treated patients }\end{array}$ \\
\hline 2. & Ueda, et al $(2008)^{3}$ & Olanzapine & $\begin{array}{l}2.5 \mathrm{mg} / \text { day and } \\
\text { increased to } 5.0 \\
\mathrm{mg} / \mathrm{day} \text { at the next } \\
\text { week }\end{array}$ & $\begin{array}{l}\text { The patient noted a reduction of } \\
\text { symptoms in a week later. The numbness } \\
\text { and irritation was relieved. }\end{array}$ \\
\hline 3. & $\begin{array}{l}\text { Stuginski-Barbosa, } \\
\text { et al }(2008)^{18}\end{array}$ & Pramipexol & $\begin{array}{l}\text { Initially pramipexol } \\
0.125 \mathrm{mg} \text { at night, } \\
\text { slowly the dose was } \\
\text { increased to } 0.75 \mathrm{mg} \\
\text { at night }\end{array}$ & $\begin{array}{l}\text { After } 4 \text { weeks of treatment, the burning } \\
\text { symptoms disappeared. Upon withdrawal } \\
\text { of pramipexol, the symptoms relapsed } \\
\text { around } 6 \text { days after, with an intensity of } \\
\text { pain around } 60 \% \text { of the baseline. }\end{array}$ \\
\hline 4. & $\begin{array}{l}\text { Lopez-Jornet, et al } \\
(2013)^{19}\end{array}$ & $\begin{array}{l}\text { Aloe Vera } \\
\text { Barbadensis } \\
\text { combination } \\
\text { with tongue } \\
\text { protector }\end{array}$ & $\begin{array}{l}\text { Topical Aloe vera } \\
(0.5 \mathrm{ml}) \text { at a } \\
\text { concentration } 70 \% \\
\text { three times a day }\end{array}$ & $\begin{array}{l}\text { Showed that the tongue protector and } \\
\text { use of topical Aloe vera might be used as } \\
\text { an alternative initial approach to BMS } \\
\text { management }\end{array}$ \\
\hline 5. & $\begin{array}{l}\text { Silvestre, et al } \\
(2012)^{20}\end{array}$ & $\begin{array}{l}\text { Capsaicin oral } \\
\text { rinse }\end{array}$ & $\begin{array}{l}\text { Oral rinse } 15 \mathrm{~mL} \text { in } 30 \\
\text { seconds }\end{array}$ & $\begin{array}{l}\text { Capsaicin was evaluated in oral rinse } \\
\text { formulation, which showed a degree of } \\
\text { efficacy in improving the symptoms of } \\
\text { BMS over short periods of times. In } \\
\text { effect, the visual analog scale (VAS) used } \\
\text { to score discomfort revealed significant } \\
\text { improvement of at least two points on } \\
\text { averaqe after } 7 \text { days of treatment. }\end{array}$ \\
\hline 6. & $\begin{array}{l}\text { Heckmann, et al } \\
(2012)^{21}\end{array}$ & $\begin{array}{l}\text { Clonazepam } \\
\text { systemic }\end{array}$ & $\begin{array}{l}\text { Clonazepam } 0.5 \mathrm{mg} \\
\text { per oral once a day }\end{array}$ & $\begin{array}{l}\text { Clonazepam has a positive effect on pain } \\
\text { in patients with BMS and does not cause } \\
\text { major side effect that would severely } \\
\text { restrict its application }\end{array}$ \\
\hline 7. & $\begin{array}{l}\text { Lopez- } \\
\text { D'alessandro et al } \\
(2011)^{22}\end{array}$ & $\begin{array}{l}\text { Combination of } \\
\text { alpha lipoic acid } \\
\text { and gabapentin }\end{array}$ & $\begin{array}{l}\text { Alpha lipoic acid } \\
600 \mathrm{mg} / \text { day } \\
\text { Gabapentin } \\
\text { 300mg/day }\end{array}$ & $\begin{array}{l}\text { Gabapentin and Alpha lipoic acid used } \\
\text { both individually and jointly, were } \\
\text { beneficial for reducing the burning in } \\
\text { patients with BMS }\end{array}$ \\
\hline 8. & $\begin{array}{l}\text { Hugoson, et al } \\
(2015)^{23}\end{array}$ & Vitamin B & $\begin{array}{l}\text { Vitamin } \mathrm{B}_{1} \text { one } 300- \\
\mathrm{mg} / \text { day for } 30 \text { days } \\
\text { Vitamin } \mathrm{B}_{2} \text { one } 10- \\
\mathrm{mg} / \text { days for } 30 \text { days } \\
\text { and Vitamin } \mathrm{B}_{6} \text { one } \\
\text { plus one plus two } 40- \\
\mathrm{mg} / \text { day for } 30 \text { days }\end{array}$ & $\begin{array}{l}\text { After } 30 \text { days of replacement therapy, } \\
\text { eight patients reported milder symptoms, } \\
\text { but the change were small. }\end{array}$ \\
\hline 9. & $\begin{array}{l}\text { Rodriguez-Cerdeira } \\
\text { et al }(2012)^{24}\end{array}$ & Amisulpride & $\begin{array}{l}\text { Amisulpride } 50 \mathrm{mg} / \text { day } \\
\text { for } 24 \text { weeks }\end{array}$ & $\begin{array}{l}\text { The amisulpride treatment regimen } \\
\text { resulted in a significant improvement in } \\
\text { BMS from the baseline at week } 6\end{array}$ \\
\hline 10. & Cho, et al $(2010)^{25}$ & Zinc supplement & $\begin{array}{l}\text { Zinc } 14,1 \mathrm{mg} / \text { day per } \\
\text { oral }\end{array}$ & $\begin{array}{l}\text { Zinc deficiencies have been related to } \\
\text { BMS, directly or indirectly giving rise to } \\
\text { various oral symptoms. Zinc replacement } \\
\text { therapy had a greater effect than other } \\
\text { symptomatic treatment in patients with } \\
\text { zinc deficiency }\end{array}$ \\
\hline
\end{tabular}

occurred in perimenopausal and postmenopausal women compared to premenopausal women (6\%). These results also showed an association between oral cavity discomfort and psychological symptoms in postmenopausal women. Two thirds of women who experience oral discomfort do not have clinical symptoms and feel reduced after Hormone Replacement Therapy (HRT). Current data shows support for the use of hormone therapy $(\mathrm{HT})$ in perimenopausal and postmenopausal women when the benefits and risks of this therapy are balanced for each individual woman. This statement reviews the effects of estrogen therapy (ET) and estrogen-progesterone therapy (EPT) on several aspects of women's health and can identify greater levels of safety associated with estrogen therapy. ${ }^{6,26,27}$ 


\section{Systemically Therapy}

Previous research examined patients who had BMS were given Olanzapine initially 2.5 $\mathrm{mg} /$ day and increased $5.0 \mathrm{mg} /$ day the following week. There was a decrease in BMS symptoms in patients taking Olanzapine in the first week. Olanzapine is a strong antagonist against a number of neuronal receptors, such as dopamine, norepinephrine, and serotonin. The efficacy of Olanzapine in BMS therapy is because it partly blocks the subset of dopamine receptors. ${ }^{3}$ Heckmann research revealed that clonazepam was effective in reducing pain experienced by BMS patients at the same time that clonazepam was well tolerated by all subjects. Clonazepam has no major effect on psychological changes and clonazepam has little impact on the patient's psychological status. The effect of clonazepam is explained by agonistic action on the GABA-inhibitor receptors which are also in the taste line. ${ }^{21}$ Rodriguez-Cerdeira research revealed that therapy with amisulpride has a good effect and tolerance on short-term BMS treatment. This is related to good adherence in the first week of treatment and a brief response to latency, especially useful in the initial treatment of BMS. ${ }^{24}$ Stuginski-Barbosa et al.(2008) ${ }^{18}$ revealed that pramipexol was given $0.125 \mathrm{mg}$ at night after 1 week the patient experienced a development of $20 \%$ (decrease from seven to five) based on Visual Analogical Scale (VAS). The dose is then slowly increased to $0.75 \mathrm{mg}$ at night, in the fourth week the complaint disappears. But after the medication was stopped, the symptoms returned on the sixth day. ${ }^{18}$ Lopez-D'alessandro et al.in 2011 stated the combination of alpha lipoic acid and Gabapentine has a good response to the burning sensation which is about $70 \%$ of people with BMS. Combinations of drugs that have different levels of action in the nociceptive system are very useful in treat- ing this disorder. ${ }^{22}$

\section{Topical Therapy}

Capsaicin acts on sensory afferent neurons, and topical capsaicin can be used as a desensitization agent or analgesic which plays a role in the treatment of burning oral mucosa. However, it's hard to accept because of its spicy taste which makes it uncomfortable when used. Furthermore, there can be an increased sensation of burning at the beginning of treatment. ${ }^{20}$ Clonazepam $1 \mathrm{mg}$ tablets are sucked by the patient then hold their saliva near the main location in the mouth without swallowing for 3 minutes and then discarded. This method is repeated three times a day for 14 days. There can be a greater reduction in pain scores in patients with clonazepam than in placebo-treated patients and suggest that the action of this drug is related to peripheral nervous system dysfunction in patients with BMS and the presence of GABA receptors in peripheral tissues. ${ }^{17,28}$ Aloe vera belongs to the Liliacea family. Topical Aloe vera has been shown to promote healing processes in the treatment of burns, psoriasis, and oral lichen planus. Lopez-Jornet et al. in 2013 found that topical application $0.5 \mathrm{ml}$ of Aloe vera gel at $70 \%$ to the tongue pain area three times a day combined with a tongue protector (transparent, low density polyethylene sheath covering the tongue from the third posterior end) is effective for reducing burning sensation and tongue pain. ${ }^{19}$

\section{Vitamin and Zinc Supplement}

Cho et al. in 2010, stated that nutritional deficiencies are involved in the cause of BMS in one third of people with BMS, including deficiencies in vitamins B1, B2, B6, B12, folic acid and zinc. Several randomized controlled trials have evaluated the effectiveness of vitamin replacement in treating patients with BMS. For example, $40 \%$ of patients with BMS, compared 
with $7.5 \%$ of the control group, found deficiencies in vitamin B1, B2, and/or B6, and this vitamin replacement therapy resolved symptoms in $30 \%$ of patients who were deficient. These findings suggest that empirical replacement with vitamin B1 (300 mg, once a day) and vitamin B6 (50 mg, three times a day) for 4 weeks may be effective in treating patients with BMS. Patients with zinc deficiency are treated with zinc supplements (14.1 mg / day) for 6 months. This finding suggests that zinc supplement therapy in BMS patients who have zinc deficiency is effective in reducing symptoms of burning in the oral cavity. ${ }^{23,25}$

\section{Reassurance}

Brailo et al. in 2016 stated that if BMS is a condition whose treatment has not been effective so that it can cause emotional conditions such as depression, anxiety, pain-related catastrophizing. ${ }^{29}$ Catastrophizing is related to anxiety that is conceptualized as a negative cognitive-affective response to pain which is a tendency to enlarge or exaggerate the value of the threat of pain sensation. This can be coupled with an inability to distract from pain. ${ }^{30,31}$ There is a study by Matsuoko, et al. in 2010 stated that reassurance has a good effect on pain perception in BMS patients. ${ }^{32}$ Reassurance can be achieved by providing objective information about conditions that reduce pain-related catastrophizing and increase the quality of life in people with BMS. Changing and eliminating a negative mindset and behavior is a very important factor in the treatment of chronic pain regardless of the causes and basic forms of cognitive behavioral therapy (CBT) and patients with BMS show a significant reduction in pain intensity and anxiety after CBT for 6 months. In addition to pain-related catastrophizing, informative intervention has a positive impact in improving quality of life. Improvement of quality life occurs after patients with BMS undergo CBT. This study emphasizes the importance of communication between dentists and patients. This is very relevant to the treatment of chronic pain such as BMS. ${ }^{29}$

\section{CONCLUSION}

Proper management of the BMS involves the combination of pharmacologic treatment such as systemic and topical therapy, as well as reassurance for stress management is an important thing.

\section{REFERENCES}

1. Abetz L, Savage N. Burning mouth syndrome and psychological disorders. Aust Dent J. 2009;54(2):84-93. doi:10.1111/j.18347819.2009.01099.x.

2. Shivpuri A, Sharma S, Trehan M, Gupta N. Burning mouth syndrome: A comprehensive review of literature. Asian J Oral Maxillofac Surg. 2011;23(4):161-166. doi:10.1016/j. ajoms.2011.06.002.

3. Ueda N, Kodama $\mathrm{Y}$, Hori H, et al. Two cases of burning mouth syndrome treated with olanzapine. Psychiatry Clin Neurosci. 2008;62(3):359361. doi:10.1111/j.1440-1819.2008.01806.x.

4. Gao J, Chen L, Zhou J, Peng J. A case-control study on etiological factors involved in patients with burning mouth syndrome. J Oral Pathol Med. 2008;38(1):24-28. doi:10.1111/j.16000714.2008.00708.x.

5. Barker KE, Batstone MD, Savage NW. Comparison of treatment modalities in burning mouth syndrome. Aust Dent J. 2009;54(4):300-305. doi:10.1111/j.1834-7819.2009.01154.x.

6. Sun A, Wu K-M, Wang Y-P, Lin H-P, Chen H-M, Chiang C-P. Burning mouth syndrome: a review and update. J Oral Pathol Med. 2013;42(9):649655. doi:10.1111/jop.12101.

7. Aravindhan R, Vidyalakshmi S, Kumar M, Satheesh C, Balasubramanium Am, Prasad Vs. Burning mouth syndrome: $A$ review on its diagnostic and therapeutic approach. J Pharm Bioallied Sci. 2014;6(5):21. doi:10.4103/0975-7406.137255.

8. Lopez-Jornet P, Camacho-Alonso F, Andujar-Mateos P, Sanchez-Siles M, Gomez-Garcia F. Burning mouth syndrome: An update. Med Oral Patol Oral y Cir Bucal. 2010;15(4):e562-e568. doi:10.4317/medoral.15.e562.

9. Ko JY, Kim MJ, Lee SG, Kho HS. Outcome predictors affecting the efficacy of clonazepam therapy for the management of burning mouth syndrome (BMS). Arch Gerontol Geriatr. 2012;55(3):755- 
761. doi:10.1016/j.archger.2011.10.001.

10. Parveen Dahiya, Reet Kamal, Mukesh Kumar, Niti, Rajan Gupta KC. Burning Mouth Syndrome and Menopause. 2013:15-20.

11. Klasser GD, Fischer DJ, Epstein JB. Burning Mouth Syndrome: Recognition, Understanding, and Management. Oral Maxillofac Surg Clin North Am. 2008;20(2):255-271. doi:10.1016/j. coms.2007.12.012.

12. Torgerson RR. Burning Mouth Syndrome. Dermatol Ther. 2010;23(3):291-298. doi:10.1111/ j.1529-8019.2010.01325.x.

13. Farronato G, Maspero C. Menopause: Changes in The Mouth Cavity and Preventive Strategies. J Womens Heal Care. 2012;1(1):1-4. doi:10.4172/2167-0420.1000102.

14. Kohorst JJ, Bruce AJ, Torgerson RR, Schenck LA, Davis MDP. A population-based study of the incidence of burning mouth syndrome. Mayo Clin Proc. 2014;89(11):1545-1552. doi:10.1016/j. mayocp.2014.05.018.

15. De Souza FTA, Teixeira AÔL, Amaral TMP, et al. Psychiatric disorders in burning mouth syndrome. J Psychosom Res. 2012;72(2):142-146. doi:10.1016/j.jpsychores.2011.11.008.

16. Luciano A de C and RFR-R. The Effect of Clonazepam Mouthwash on the Symptomatology of Burning Mouth Syndrome : An Open Pilot Study. 2014:2164-2167.

17. Grémeau-Richard C, Dubray C, Aublet-Cuvelier B, Ughetto S, Woda A. Effect of lingual nerve block on burning mouth syndrome (stomatodynia): A randomized crossover trial. Pain. 2010;149(1):27-32. doi:10.1016/j. pain.2009.11.016.

18. Stuginski-Barbosa J, Rodrigues GGR, Bigal ME, Speciali JG. Burning mouth syndrome responsive to pramipexol. J Headache Pain. 2008;9(1):4345. doi:10.1007/s10194-008-0003-4.

19. López-Jornet $P$, Camacho-Alonso F, Molino-Pagan D. Prospective, randomized, double-blind, clinical evaluation of Aloe vera Barbadensis, applied in combination with a tongue protector to treat burning mouth syndrome. J Oral Pathol Med. 2013;42(4):295-301. doi:10.1111/ jop.12002.

20. Silvestre FJ, Silvestre-Rangil J, Tamarit-Santafé C, Bautista D. Application of a capsaicin rinse in the treatment of burning mouth syndrome. Med Oral Patol Oral Cir Bucal. 2012;17(1):2-5. doi:10.4317/medoral.17219.

21. Heckmann SM, Kirchner E, Grushka M, Wichmann MG, Hummel T. A double-blind study on clonazepam in patients with burning mouth syndrome. Laryngoscope. 2012;122(4):813-816. doi:10.1002/lary.22490.

22. Lopez-D alessandro E, Escovich L. Combination of alpha lipoic acid and gabapentin, its efficacy in the treatment of Burning Mouth Syndrome: A randomized, double-blind, placebo controlled trial. Med Oral Patol Oral y Cir Bucal. 2011;16(5):635-
640. doi:10.4317/medoral.16942.

23. Hugoson A, Thorstensson B. Vitamin b status and response to replacement therapy in patients with burning mouth syndrome. Acta Odontol Scand. 2015;49(6):367-375. doi:10.3109/00016359109005933.

24. Rodriguez-Cerdeira. Treatment of Burning Mouth Syndrome With Amisulpride. J Clin Med Res. 2012. doi:10.4021/jocmr972w.

25. Cho GS, Han MW, Lee B, et al. Zinc deficiency may be a cause of burning mouth syndrome as zinc replacement therapy has therapeutic effects. J Oral Pathol Med. 2010;39(9):722-727. doi:10.1111/j.1600-0714.2010.00914.x.

26. Meurman JH, Tarkkila L, Tiitinen A. The menopause and oral health. Maturitas. 2009;63(1):5662. doi:10.1016/j.maturitas.2009.02.009.

27. Gass MLS, Manson JE, Cosman F, et al. The 2012 hormone therapy position statement of the North American Menopause Society. Menopause. 2012;19(3):257-271. doi:10.1097/ gme.0b013e31824b970a.

28. de Castro LA, Ribeiro-Rotta RF. The effect of clonazepam mouthwash on the symptomatology of burning mouth syndrome: An open pilot study. Pain Med (United States). 2014;15(12):21642166. doi:10.1111/pme.12552.

29. Brailo $V$, Firić $M$, Vučićević Boras $V$, Andabak Rogulj A, Krstevski I, Alajbeg I. Impact of reassurance on pain perception in patients with primary burning mouth syndrome. Oral Dis. 2016;22(6):512-516. doi:10.1111/odi.12493.

30. Quartana PJ, Campbell CM, Edwards RR. Pain catastrophizing a critical review. Expert Rev Neurother. 2009;9(5):745-758. doi:10.1586/ ern.09.34.

31. Schütze R, Rees $C$, Preece $M$, Schütze $M$. Low mindfulness predicts pain catastrophizing in a fear-avoidance model of chronic pain. Pain. 2010;148(1):120-127. doi:10.1016/j. pain.2009.10.030.

32. Matsuoka H, Himachi M, Furukawa H, et al. Cognitive profile of patients with burning mouth syndrome in the Japanese population. Odontology. 2010;98(2):160-164. doi:10.1007/s10266-0100123-6. 